\title{
Differentiation of Coxiella burnetii isolates by analysis of restriction- endonuclease-digested DNA separated by SDS-PAGE
}

\author{
Laura R. Hendrix, James E. Samuel $\dagger$ and Louis P. Mallavia* \\ Department of Microbiology, Washington State University, Pullman, Washington 99164-4233, USA
}

(Received 29 May 1990; revised 23 August 1990; accepted 25 September 1990)

\begin{abstract}
Thirty-two isolates of Coxiella burnetii collected from various hosts ranging from arthropods to man were compared by restriction endonuclease (RE) digestion patterns of chromosomal DNA using SDS-PAGE. SDSPAGE provided better DNA fragment separation than agarose gel electrophoresis and enabled the differentiation of these isolates into six distinct groups on the basis of DNA restriction fingerprints. Two groups of chronic disease isolates could be distinguished, each having unique RE digestion patterns of chromosomal DNA. Three similar but distinct RE digestion patterns were seen among the group of acute disease isolates. Three additional isolates included in this study exhibited a unique RE digestion pattern and also had a unique plasmid type, designated QpDG. DNA-DNA hybridization on selected isolates quantified the relatedness between several groups and supported the classification of these groups as distinct strains.
\end{abstract}

\section{Introduction}

Coxiella burnetii, a rickettsial agent, causes a wide spectrum of human disease. $Q$ fever is an acute flu-like illness which is self-limiting or easily treated with antibiotics. Other serious and more difficult-to-treat conditions which can result from infection include pneumonia, hepatitis and chronic endocarditis. The organism has also been implicated as the causative agent of late-term abortion in goats and has been isolated from an extremely wide range of animals and arthropods (Baca \& Paretsky, 1983). Despite this wide range of both disease and host, conventional serological methods have failed to discriminate between $C$. burnetii isolates (Topping et al., 1946; Peacock et al., 1983). Recent studies have indicated that $C$. burnetii isolates can be differentiated by several parameters, including the presence of unique plasmid sequences and lipopolysaccharide (LPS) differences. Isolates contained one of two plasmid types or were plasmidless (Samuel et al., 1985; Vodkin et al., 1986). Polyacrylamide gel electrophoresis (PAGE) showed that LPS banding patterns also varied among isolates (Hackstadt, 1986). Both analyses allow the differentiation of isolates into at least three major groups (Samuel et al., 1985). These groups do not

† Present address: BioCarb Inc, Gaithersburg, Maryland 20879, USA.

Abbreviation: RE, restriction endonuclease. correlate with host, geographical location, or date of isolation. However, the type of human disease caused by isolates in each group is similar: two groups contain isolates from chronic endocarditis cases and no acute disease isolates, while another group contains acute disease isolates and no isolates from humans with chronic disease. This implies that specific isolate groups have a particular virulence potential in humans.

A previous report that compared the banding patterns of $C$. burnetii chromosomal DNA digested by restriction endonucleases (REs) and separated by agarose gel electrophoresis was unable to identify any differences that were consistently associated with phase variation (O'Rourke et al., 1985). To more clearly understand the degree of relatedness between isolate groups, in the present work we used SDS-PAGE separation of REdigested DNA, which provides much better resolution than electrophoresis on agarose gels, to compare chromosomal DNA from each isolate. DNA-DNA hybridization analysis on selected isolates was also performed to quantify the relatedness between groups. A preliminary report of these data has been previously presented (Mallavia et al., 1985).

\section{Methods}

Isolates. Each isolate in this study came from an animal infection or was derived by long-term passage (animal, tissue culture or egg, or combinations thereof) of a clinical isolate and was subsequently 
defined as an independent isolate. The isolates were obtained from M. G. Peacock, Rocky Mountain Laboratories, National Institute of Allergy and Infectious Diseases, Hamilton, MT, USA, or were cultured at the Washington State University Biocontainment Laboratory (H WSU 101). Name, catalogue number, origin, and passage history for each isolate are shown in Table 1. Most of these isolates have been described previously (Samuel et al., 1985); they include representatives from the diversity of warm-blooded animals and arthropods from which $C$. burnetii has been recovered. The human isolates were from acute $Q$ fever infections, endocarditis cases, and one case of endocarditis subsequently recategorized as hepatitis (Peacock $e t$ al., 1983). Animal isolates were derived from one sheep abortion and four goat abortions, three wild rodents, and the milk of three persistently infected cows. Several isolates (including Nine Mile RSA493) were obtained from ticks. One human isolate, American Q Dyer, is thought to have resulted from a laboratory-acquired infection with the Nine Mile RSA493 isolate (Topping et al., 1946). The passage history refers to the subculturing of each isolate prior to propagation by our laboratory. The phase character of each isolate refers to reactivity with phase I or phase II hyperimmune serum in a complement block titration assay (Peacock et al., 1983).

Propagation and purification of rickettsiae. Suspensions of infected yolk sacs or guinea-pig spleens which had been stored at $-80^{\circ} \mathrm{C}$ were inoculated into 6-d-old, embryonated chick eggs ( $\mathrm{H}$ and $\mathrm{N}$ Hatchery, Redmond, WA, USA). Infected yolk sacs of viable embryos were harvested when significant numbers ( $>20 \%$ ) of embryos died, or $2-3 \mathrm{~d}$ before hatching if death did not occur. Rickettsiae were purified from the infected yolk sacs as described previously (Hendrix \& Mallavia, 1984).

DNA extraction. Purified $C$. burnetii organisms (up to $20 \mathrm{mg}$ dry weight) were suspended in $20 \mathrm{mM}-\mathrm{Tris} / \mathrm{HCl}, 50 \mathrm{mM}-\mathrm{NaCl}(\mathrm{pH} 9 \cdot 1)$ and lysed with thermolysin and SDS as reported previously (Samuel et al., 1983). Lysates were centrifuged to equilibrium on caesium chloride gradients with ethidium bromide $(\mathrm{CsCl} / \mathrm{EtBr})$ at $200000 \mathrm{~g}$ for $16 \mathrm{~h}$ in a Beckman Vti80 rotor. DNA bands were located with UV light and the upper chromosomal band collected. The $\mathrm{EtBr}$ was removed by extraction with $1 \times \operatorname{SSC}(0.15 \mathrm{M}-\mathrm{NaCl}, 0.015 \mathrm{M}$-sodium citrate, $\mathrm{pH} 7)$ saturated 2-propanol and the DNA precipitated in 2-propanol at $-20^{\circ} \mathrm{C}$ overnight. The DNA was pelleted by centrifugation at $10000 \mathrm{~g}$ and extracted twice in $1: 1(\mathrm{v} / \mathrm{v})$ buffered phenol/chloroform (Maniatis et al., 1982). The DNA was then precipitated in absolute ethanol containing $0.3 \mathrm{M}$-ammonium acetate at $-20^{\circ} \mathrm{C}$ for $2 \mathrm{~h}$, pelleted, washed with $95 \%(\mathrm{v} / \mathrm{v})$ ethanol and resuspended in a small volume of $10 \mathrm{~mm}$-Tris/HCl, l mM-EDTA (pH 7.4). Although isolated chromosomal DNA was used in these studies, it was recognized that nicked plasmid DNA was also present in these preparations.

Restriction endonuclease treatment and electrophoresis. Restriction enzymes were obtained from New England Biolabs or Bethesda Research Laboratories. DNA was digested with approximately $5 \mathrm{U}$ enzyme $(\mu \mathrm{g} \text { DNA })^{-1}$ for $2 \mathrm{~h}$ using conditions recommended by the manufacturer. RNAase A $\left(10 \mu \mathrm{g} \mathrm{ml}^{-1}\right)$ was added to each DNA sample before digestion. The DNA was extracted once after digestion with an equal volume of phenol/chloroform to remove restriction enzymes, which also stain with silver stain and can obscure the DNA fragment bands.

SDS-PAGE was carried out under the conditions described by Laemmli (1970). Gels were $160 \times 320 \times 1.5 \mathrm{~mm}$ and were run at $7.5 \mathrm{~mA}$ for approximately $24 \mathrm{~h}$ with constant cooling. The discontinuous gels consisted of a $7.5 \%$ (w/v) separating gel with a $15 \mathrm{~mm}$ deep stacking gel of $3 \%(w / v)$ polyacrylamide. Each well was loaded with 1-3 $\mu \mathrm{g}$ of restriction-enzyme-digested DNA in Laemmli sample buffer. Gels were stained with silver by the method described by Herring $e t$ al. (1982) with the modification of McClenaghan et al. (1984) to remove
SDS and glycine. Gels were photographed on a light box using an $80 \mathrm{~B}$ Wratten filter and Polaroid type 55 film.

Probe preparation and Southern blot hybridization. Nick-translation and Southern blot hybridization were performed as previously described (Samuel et al., 1985). The probe consisted of nick-translated plasmid QpHI DNA. Blots were hybridized at $68^{\circ} \mathrm{C}$ in $5 \times \mathrm{SSC}$, $10 \times$ Denhardt's solution $(1 \times$ Denhardt's solution is $0.02 \%$ bovine serum albumin, $0.02 \%$ Ficoll, $0.02 \%$ polyvinylpyrrolidone), $50 \mathrm{~mm}$ Tris/ $\mathrm{HCl}, \mathrm{pH} 8.0,5 \mathrm{~mm}$-EDTA and washed for $30 \mathrm{~min}$, four times, with $1 \times \mathrm{SSC}$ at $68^{\circ} \mathrm{C}$ to provide stringent conditions.

DNA solution hybridization. The similarity of chromosomal $C$. burnetii DNA from various isolates was measured by DNA hybridization as described by deLay (1970) and specifically adapted as follows. Purified rickettsiae were lysed with thermolysin and $1 \%(w / v)$ SDS and the chromosomal DNA purified as above. The DNA was then treated with phenol/chloroform followed by chloroform extraction and dialysed against $2 \times \mathrm{SSC}$ overnight. The DNA solution, adjusted to an $A_{260}$ of 4.0 , was sonicated for $2 \mathrm{~min}$ at $30 \%$ power with a Fisher sonicator to generate randomly cleaved DNA fragments $600 \pm 300 \mathrm{bp}$ in length. The solution of fragmented DNA was then used at an $A_{260}$ of 1.0 in hybidizations with each isolate group. Thermal renaturations were done on a Beckman DU-8 spectrophotometer with $T_{\mathrm{m}}$ software (Beckman Instruments) and temperature-controlled cuvettes with $2 \times \mathrm{SSC}$ as a blank. Samples were raised to $10{ }^{\circ} \mathrm{C}$ above the $T_{\mathrm{m}}$ as calculated by the formula $T_{\mathrm{m}}=0.41(\mathrm{~mol} \% \mathrm{G}+\mathrm{C})+69+13.3 \mathrm{log}$ [Na]. For $C$. burnetii DNA, the $T_{\mathrm{m}}$ is $81.6^{\circ} \mathrm{C}$. The temperature was quickly ( $<2 \mathrm{~min}$ ) reduced to the optimal renaturation temperature as calculated by $T_{\mathrm{or}}=1 \cdot 24 T_{\mathrm{m}}-38.8$. The calculated value for $C$. burnetii DNA is $73{ }^{\circ} \mathrm{C}$. The rate of change of $\boldsymbol{A}_{260} \mathrm{~min}^{-1}$ was determined over a $30 \mathrm{~min}$ period. The degree of hybridization $(D)$ between DNA samples from two isolates was determined by the formula $D=4 V_{\mathrm{m}}-\left(V_{\mathrm{A}}+\right.$ $V_{\mathrm{B}} / 2 \sqrt{ } V_{\mathrm{A}} V_{\mathrm{B}}$, where $V_{\mathrm{m}}$ is the decrease in $A_{260}$ of the mixture of DNA samples from both isolates, $V_{\mathrm{A}}$ is the decrease in $A_{260}$ of the DNA sample from one isolate, and $V_{\mathrm{B}}$ is the decrease in $A_{260}$ of the DNA sample from the second isolate.

\section{Results}

\section{$R E$-digested chromosomal DNA separated by $S D S-P A G E$}

The banding patterns of RE-generated DNA fragments of chromosomal DNA allowed each C. burnetii isolate to be placed into one of six groups. The resolution of the DNA fragments by agarose gel electrophoresis was not sufficient to allow a close comparison of the RE banding patterns between isolates. For this reason, a procedure using long-gel $(320 \mathrm{~mm})$ SDS-PAGE and silver staining similar to the technique reported by McClenaghan $e t$ al. (1984) for Chlamydia psittaci was used. The result was a dramatic increase in resolution of the DNA fragments and, therefore, an increase in the sensitivity of comparison. Fig. 1 shows the results obtained after digestion of DNA from several isolates with $E c o$ RI and separation of the fragments on SDS-PAGE. The DNA of isolates that had similar fragment patterns after digestion with BamHI (Fig. 2) also exhibited similar patterns when digested with EcoRI (Fig. 1). The groupings did not 

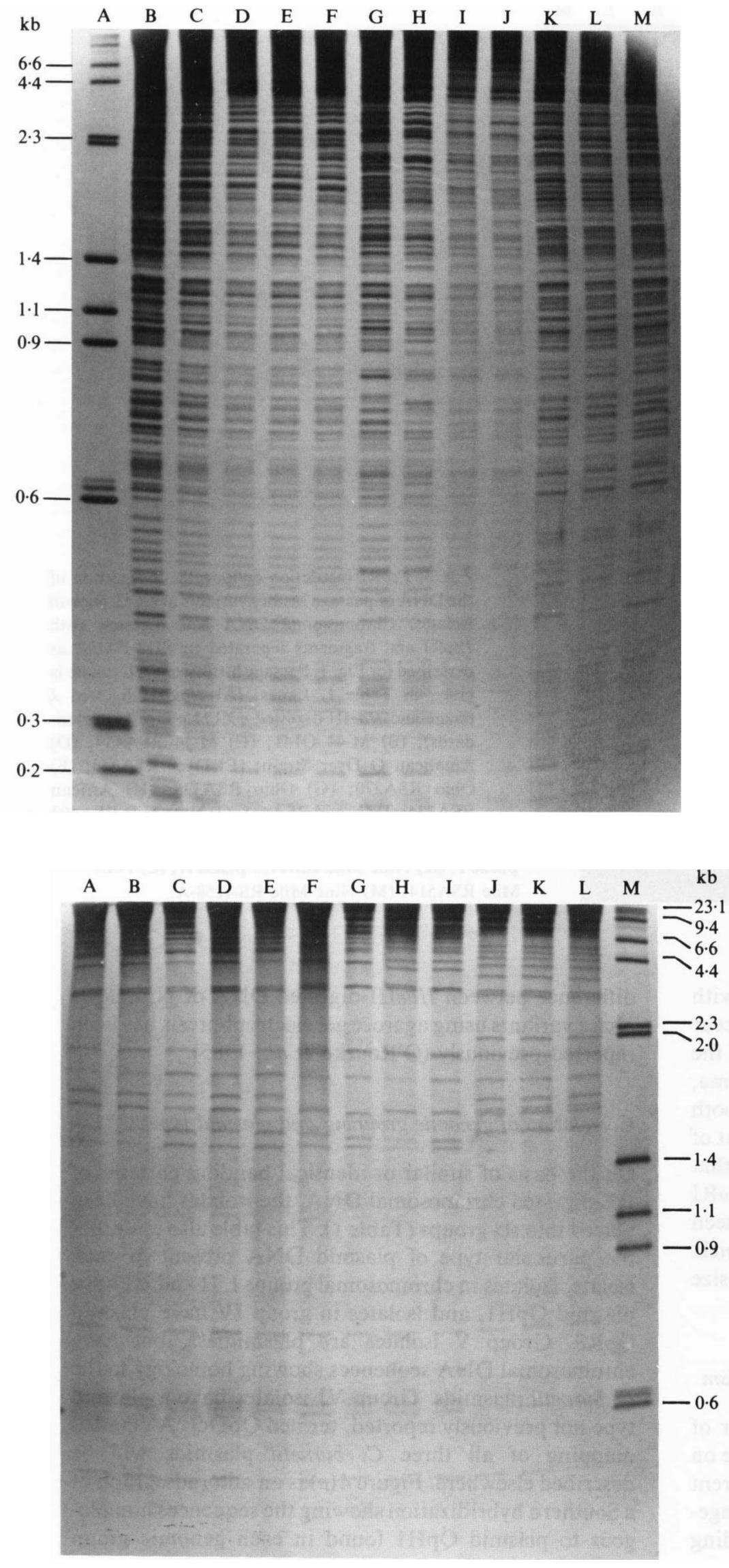

Fig. 1. EcoRI restriction endonuclease digestion of the DNA of twelve $C$. burnetii isolates. Chromosomal DNA was digested with EcoRI and fragments separated by SDS-PAGE on a $7.5 \%$ gel using Laemmli buffers. DNA bands were visualized by silver staining. Lanes: (A) HindIII-digested $\lambda$ phage and HaelII-digested $\phi \times 174$ phage (size standards); (B) MSU Goat Q177; (C) K Q154; (D) F Q228; (E) PQ173; (F) Canada Goat Q218; (G) Nine Mile RSA493 phase I; (H) Goat Q195; (I) M-44 RSA459; (J) Henzerling RSA331; (K) L Q216; (L) G Q212; (M) S Q217.

Fig. 2. BamHI restriction endonuclease digestion of the DNA of twelve $C$. burnetii isolates. Chromosomal DNA was digested with BamHI and fragments separated by SDS-PAGE as described for Fig. 1 . Lanes: (A) MSU Goat Q177; (B) K Q154; (C) F Q228; (D) P Q173; (E) Canada Goat Q218; (F) Nine Mile RSA493 phase I; (G) Goat Q195; (H) M44 RSA459; (I) Henzerling RSA331; (J) L Q216; (K) G Q212; (L) S Q217; (M) HindIII-digested $\lambda$ phage and HaeIII-digested $\phi \mathrm{X} 174$ phage (size standards). 


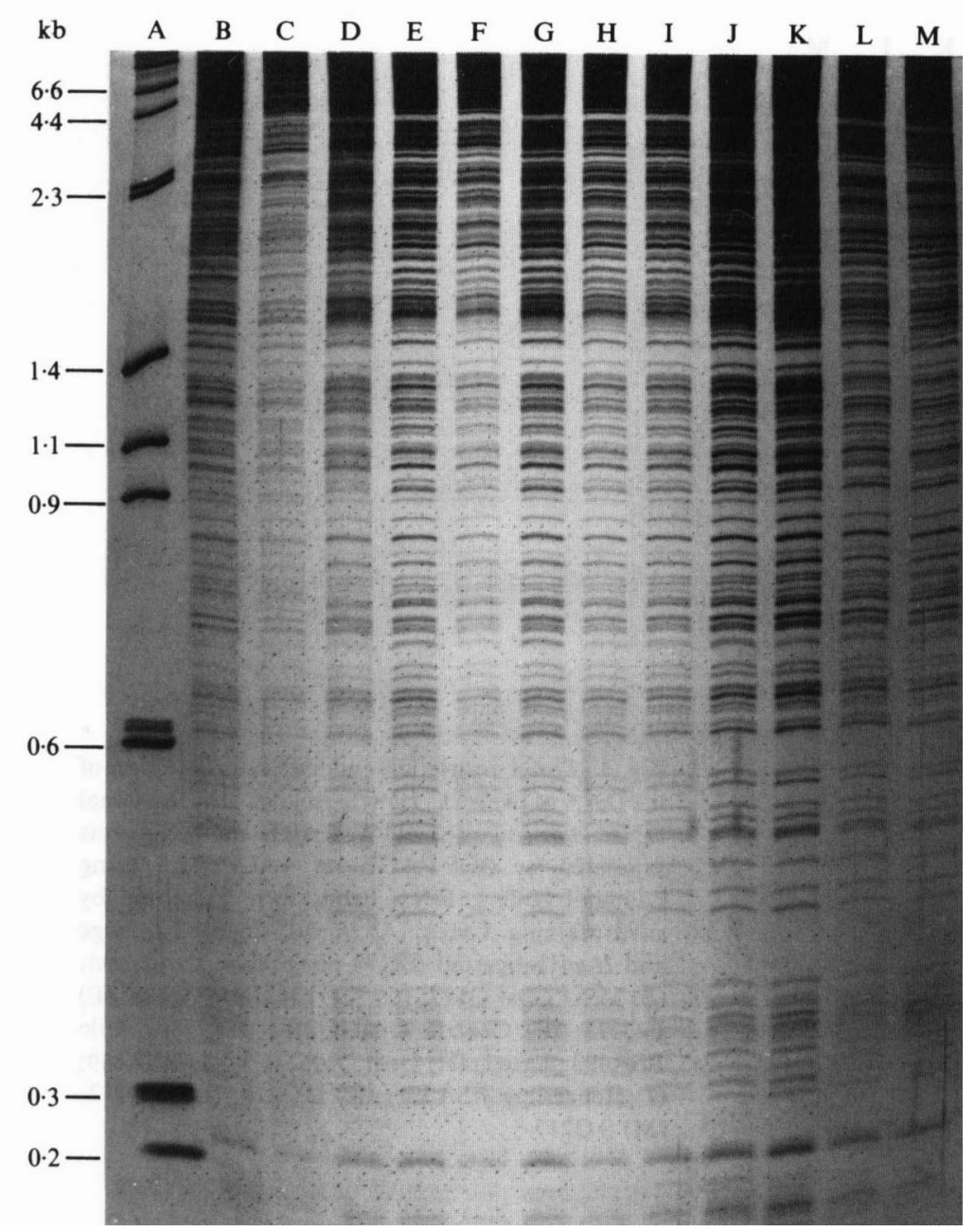

Fig. 3. EcoRI restriction endonuclease digestion of the DNA of passage history variants of six C. burnetii isolates. Chromosomal DNA was digested with EcoRI and fragments separated by SDS-PAGE as described for Fig. 1. Passage history of each isolate is given in Table 1. Lanes: (A) HindIII-digested $\lambda$ phage and HaellI-digested $\phi \times 174$ phage (size standards); (B) M-44 Q141; (C) M-44 RSA459; (D) American Q Dyer Strain; (E) Dyer RSA345; (F) Ohio RSA270; (G) Ohio RSA338; (H) African RSA334; (I) Giroud RSA431 ; (J) Nine Mile RSA493 phase I; (K) Nine Mile RSA439 phase II; (L) Nine Mile RSA514; (M) Nine Mile RSA258-A.

change when the DNA samples were digested with HindIII (data not shown). Minor differences did occur within a group. For example, the DNA of several of the isolates in genomic group I [El Tayeb, Panama, California 33 and California 16, and Ohio 314 (both RSA270 and RSA330)] had an extra BamHI fragment of approximately $4 \mathrm{~kb}$ compared to the other isolates in that group, but appeared identical when digested with EcoRI (data not shown). The differences were more easily seen when the rickettsial DNA was digested with BamHI (Fig. 2) because fewer bands were produced in the size range best resolved by SDS-PAGE.

\section{Effect of passage history on restriction site polymorphism}

Fig. 3 shows EcoRI-digested DNA from a number of isolates which differed from at least one other isolate on the gel only in terms of passage history. No apparent differences in RE band patterns between the passagehistory variants could be seen. One specific banding difference between HaelII-digested DNA of Nine Mile phase variants using agarose gel electrophoresis has been reported previously (O'Rourke et al., 1985).

\section{Correlation of genomic grouping and plasmid type}

On the basis of similar or identical banding patterns of RE-digested chromosomal DNA, the isolates have been placed into six groups (Table 1). This table also identifies the particular type of plasmid DNA present in each isolate. Isolates in chromosomal groups I, II and III have plasmid QpH1, and isolates in group IV have plasmid QpRS. Group V isolates are plasmidless, but have chromosomal DNA sequences showing homology to the C. burnetii plasmids. Group VI isolates have a plasmid type not previously reported, termed QpDG. A detailed mapping of all three $C$. burnetii plasmids will be described elsewhere. Figure $4(a)$ is an autoradiograph of a Southern hybridization showing the sequences homologous to plasmid QpH1 found in each genomic group 
Table 1. Isolates of C. burnetii

\begin{tabular}{|c|c|c|c|c|c|c|}
\hline $\begin{array}{l}\text { Genomic } \\
\text { group* }\end{array}$ & $\begin{array}{l}\text { Plasmid } \\
\text { type } \dagger\end{array}$ & Isolate & Phase $\S$ & Original source & Disease & Passage $\|$ \\
\hline \multirow[t]{16}{*}{ I } & \multirow[t]{16}{*}{ QpHl } & Nine Mile RSA493 & I & Montana, tick, 1935 & - & $307 \mathrm{GP} / 1 \mathrm{TC} / 1 \mathrm{EP}$ \\
\hline & & Nine mile RSA439ף & II & Montana, tick, 1935 & - & $90 \mathrm{EP} / 1 \mathrm{TC} / 1 \mathrm{EP}$ \\
\hline & & Nine mile RSA514T & $\mathrm{I} / \mathrm{II} \#$ & Montana, tick, 1935 & - & $4 \mathrm{EP} / 306 \mathrm{GP} / 3 \mathrm{EP}$ \\
\hline & & Nine mile RSA285-Aף & $\mathrm{I} / \mathrm{II} \#$ & Montana, tick, 1935 & - & $4 \mathrm{EP} / 306 \mathrm{GP} / 3 \mathrm{EP}$ \\
\hline & & Dyer RSA 345 & II & USA, human blood, 1938 & Acute & $81 \mathrm{EP}$ \\
\hline & & American Q Dyer $\uparrow$ & I & USA, human blood, 1938 & Acute & $75 \mathrm{EP} / 1 \mathrm{GP}$ \\
\hline & & Australia QD RSA425 & II & Australia, human blood, $\sim 1939$ & Acute & $177 \mathrm{EP}$ \\
\hline & & Turkey RSA333 & II & Turkey, human blood, 1948 & Acute & $31 \mathrm{EP}$ \\
\hline & & African RSA334 & I & Central Africa, human blood, 1949 & Acute, Congolese Red Fever & $3 \mathrm{HP} / 4 \mathrm{EP}$ \\
\hline & & Giroud RSA4319 & I & Central Africa, human blood, 1949 & Acute, Congolese Red Fever & $2 \mathrm{GP} / 2 \mathrm{EP}$ \\
\hline & & El Tayeb RSA342 & I & Egypt, tick, 1967 & - & 4GP/2EP \\
\hline & & Panama RSA335 & I & Panama,chiggers, 1961 & - & 4EP \\
\hline & & California 33 RSA329 & I & California, cow's milk, 1947 & Persistent & $6 \mathrm{EP}$ \\
\hline & & California 16 RSA350 & II & California, cow's milk, 1947 & Persistent & $38 \mathrm{EP}$ \\
\hline & & Ohio 314 RSA270 & I & Ohio, cow's milk, 1956 & Persistent & 4EP \\
\hline & & Ohio 314 RSA338 & II & Ohio, cow's milk, 1956 & Persistent & 42EP \\
\hline \multirow[t]{3}{*}{ II } & \multirow[t]{3}{*}{ QpHl } & $M-44 R S A 459$ & II & Italo-Greek, 'Grita', $\sim 1945$ & Acute & $? / 2 \mathrm{EP}$ \\
\hline & & M-44 Q141ণ & II & Italo-Greek, 'Grita', 1945 & Acute & $? / 1 \mathrm{GP} / 2 \mathrm{EP}$ \\
\hline & & Henzerling RSA331 & II & Italy, human blood, 1945 & Acute & $36 \mathrm{EP}$ \\
\hline \multirow[t]{3}{*}{ III } & \multirow[t]{3}{*}{ QpH1 } & Idaho Goat Q195 & I & Idaho, goat, 1981 & Abortion & $2 \mathrm{EP}$ \\
\hline & & Idaho Goat & I & Idaho, goat placenta, 1975 & Abortion & $5 \mathrm{EP}$ \\
\hline & & Koka & I & Ethiopia, tick, 1963 & - & 1GP/6EP \\
\hline \multirow[t]{7}{*}{ IV } & \multirow[t]{7}{*}{ QpRS } & MSU Goat Q177 & I & Montana, goat cotyledon, 1980 & Abortion & GP/2EP \\
\hline & & Canada Goat Q218 & I & Ontario, Canada, goat spleen, 1981 & Abortion & $1 \mathrm{GP} / 1 \mathrm{EP}$ \\
\hline & & Idaho Sheep $80-1$ & I & Idaho sheep liver, 1980 & Abortion & $1 \mathrm{GP} / 4 \mathrm{EP}$ \\
\hline & & K Q154 & I & Oregon, human heart valve, 1976 & Endocarditis & $\mathrm{HV} / 2 \mathrm{EP}$ \\
\hline & & P Q173 & I & California, human heart valve, 1979 & Endocarditis & $\mathrm{HV} / 2 \mathrm{EP}$ \\
\hline & & F Q228 & I & Washington, human heart valve, 1982 & Endocarditis & $\mathrm{HV} / 3 \mathrm{EP}$ \\
\hline & & H WSU101 & I & California, human heart valve, 1986 & Endocarditis & $\mathrm{HV} / 2 \mathrm{EP}$ \\
\hline \multirow[t]{4}{*}{$\mathrm{v}$} & \multirow[t]{4}{*}{ NP } & $L Q 216$ & I & Nova Scotia, human heart valve, 1981 & Endocarditis & $\mathrm{HV} / 2 \mathrm{EP}$ \\
\hline & & $\mathrm{G} \mathrm{Q} 212$ & I & Nova Scotia, human heart valve, 1981 & Endocarditis & HV $/ 2 \mathrm{EP}$ \\
\hline & & S Q217 & I & Montana, human liver biopsy, 1981 & Hepatitis & BX/2EP \\
\hline & & Ko Q229 & I & Nova Scotia, human heart valve, 1982 & Endocarditis & $\mathrm{HV} / 2 \mathrm{EP}$ \\
\hline \multirow[t]{3}{*}{ VI } & \multirow[t]{3}{*}{ QpDG } & Dugway $7 E 22-57$ & I & Utah, rodents, 1958 & - & $3 \mathrm{EP}$ \\
\hline & & Dugway 7E9-12 & I & Utah, rodents, 1958 & - & 3EP \\
\hline & & Dugway $7 \mathrm{E} 65-68$ & I & Utah, rodents, 1958 & - & $3 \mathrm{EP}$ \\
\hline
\end{tabular}

* As defined by restriction enzyme banding patterns described herein.

† Plasmids described (Samuel et al., 1985).

$\ddagger$ Provided by Rocky Mountain Laboratories, National Institute of Allergy and Infectious Disease, Hamilton, MT, USA. Reference strains are italicized.

$\S$ Determined by complement block titration, M. G. Peacock, Rocky Mountain Laboratories.

\| Preceding number indicates passage number; GP, guinea-pig passage; TC, tissue culture; EP, egg passage; HP, hamster passage; HV, heart valve; BX, liver biopsy; ?, passage prior to receipt in authors' laboratory not known.

If Passage history variants.

\# Phase I antigens easily removed.

when chromosomal DNA was digested with EcoRI and probed with radiolabelled plasmid QpH1. Although a minor component of plasmid DNA was resolved with the chromosomal DNA, the majority of differences in the chromosomal DNA fingerprints (Fig. $4 b$ ) are not due to the plasmid variability previously reported (Samuel $e t$ al., 1985). For example, the banding patterns of plasmids QpH1, QpRS, and QpDG digested with BamHI each have only three fragments, which are identical in size, under $3.5 \mathrm{~kb}$ (data not shown). Therefore, the differences seen in the banding patterns of BamHI chromosomal digests are not due to plasmid differences. On the other hand, S Q217 and MSU Goat Q177 have several differences in their chromosomal DNA fingerprints, such as a $3.4 \mathrm{~kb}$, a $1.9 \mathrm{~kb}$ and a $1.5 \mathrm{~kb}$ band found in S Q217 (Fig. 4b, lane B) but not found in MSU Goat Q177. S Q217 is grouped with those isolates which do not contain a plasmid, although it does have plasmid-related sequences integrated into the chromosome (E. Savinelli, unpublished). The correlation between the genomic 


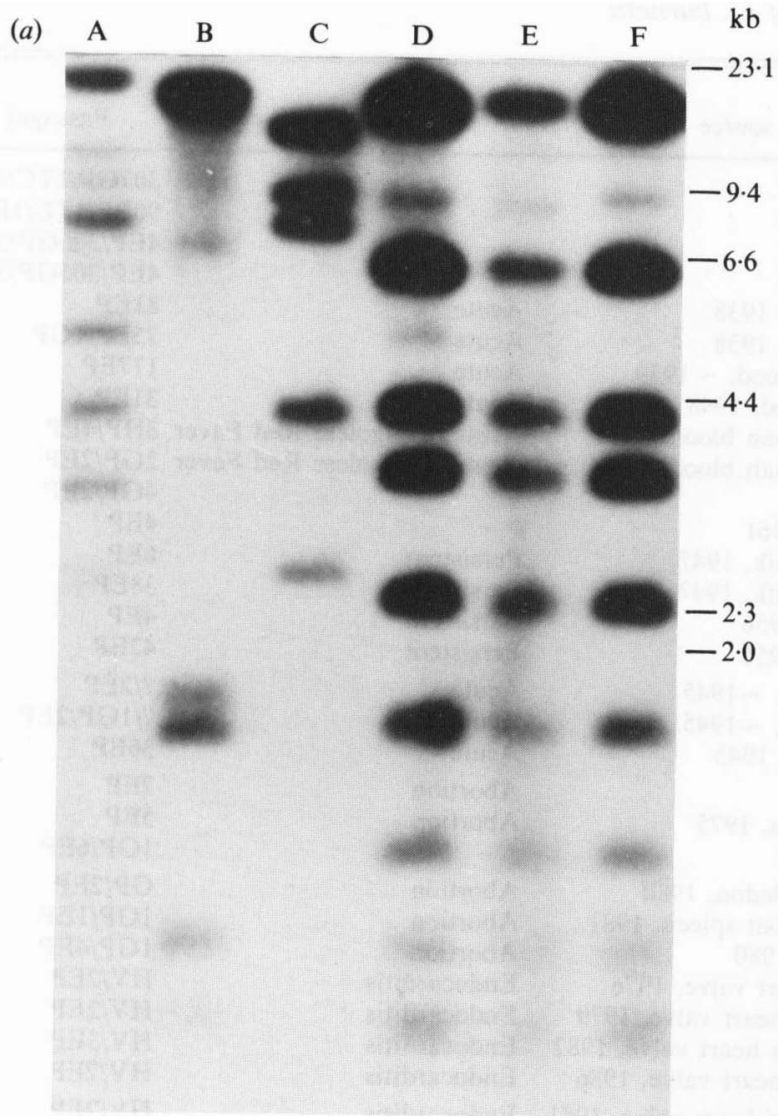

Fig. 4. (a) Autoradiograph of plasmid QpH1 DNA probe hybridization with DNA of one $C$. burnetii isolate from each genomic group. Chromosomal DNA extracted from each organism was digested with EcoRI and separated by electrophoresis on a $0.9 \%$ agarose gel in Tris/acetate buffer. A Southern blot was prepared from the agarose gel and hybridized with a nick-translated $\mathrm{QpH} 1$ probe using conditions allowing for aproximately $20 \%$ mismatch of sequences. Lanes: (A) Dugway 7E9-12; (B) S Q217; (C) MSU Goat Q177; (D) Nine Mile RSA493 phase I; (E) M-44 RSA459; (F) Idaho Goat Q195. Markers indicate fragment size of $\lambda$ phage DNA digested with HindIII. (b) $B a m H I$ restriction endonuclease digestion of the DNA of one $C$. burnetii isolate from each genomic group. Chromosomal DNA was digested with BamHI and fragments separated by SDS-PAGE as described in Fig. 1. Lanes as in (a). Markers indicate fragment sizes of $\lambda$ phage DNA digested with HindIII and of $\phi$ X174 phage DNA digested with HaeIII.

grouping shown in Fig. 4(b) and the plasmid type (Fig. $4 a$ ) confirms the uniqueness of each isolate group but does not quantify their relatedness.

\section{Quantification of group variation measured by DNA-DNA hybridization}

To quantify the relatedness of isolates within and between chromosomal groups, DNA-DNA hybridiza-

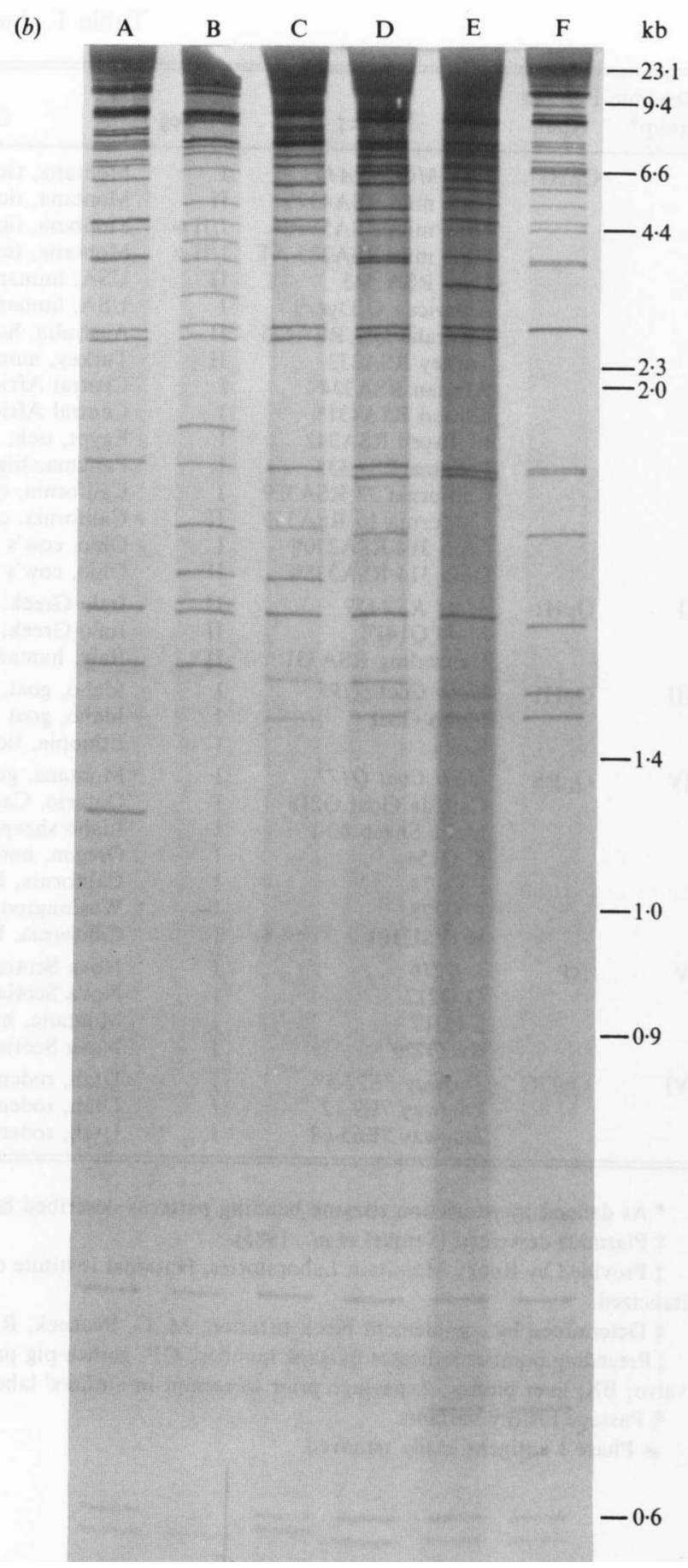

tion analysis on selected isolates was performed (Table 2). This type of analysis has previously been performed with various Rickettsia spp. and was used to assign relatedness at the strain level (Myers \& Wisseman, 1980). Two isolates, Nine Mile RSA493 and Dyer RSA345, were included in the present comparison to demonstrate relatedness within a genomic group. In fact, Nine Mile RSA493 and Dyer RSA345 are essentially passage history variants of the same original isolate. Group VI 
Table 2. DNA-DNA hybridization between isolate groups of C. burnetii

The degree of hybridization was determined twice for each pair of strains, each time with separately prepared DNA. The $D$ value is a mean of these two measurements expressed \pm the standard deviation of the mean. ND, Not determined.

\begin{tabular}{lcccc}
\hline \hline \multirow{2}{*}{$\begin{array}{c}\text { Reference } \\
\text { DNA }\end{array}$} & Nine Mile* & Dyer† & Dugway & MSU Goat $\S$ \\
\cline { 2 - 5 } & - & $101 \pm 1$ & $90 \pm 5$ & $92 \pm 4$ \\
Nine Mile* & - & ND & $95 \pm 2$ & - \\
MSU Goat§ & $92 \pm 4$ & value (\%) \\
\hline \hline
\end{tabular}

* RSA493, genomic group I.

† RSA345, genomic group I.

$\ddagger 7 \mathrm{E} 22-57$, genomic group VI.

$\S$ Q177, genomic group IV.

(Dugway 7E22-57) and group IV (MSU Goat Q177) isolates were included to measure relatedness between distinct genomic groups on the basis of DNA fragment analysis. Due to the large amount of DNA required for hybridization analysis, isolates from groups II, III and V were not included in this study, as they were typically more diffficult to propagate to high titre. Within one group, Nine Mile RSA493 and Dyer RSA345 had $101 \pm 2 \%$ homology as measured by the hybridization value $(D)$. This result would be predicted from their aetiological relationship. Between genomic groups, $D$ values ranged from 90 to $95 \%$. These values were an average of two independent experiments for each comparison, with separately prepared DNA used for each experiment. The standard deviation of the average hybridization $(D)$ between the two experiments ranged from $2 \%$ to $5 \%$ but, because of the small number of samples in the comparison of experiments $(n=2)$, these values were not statistically significantly different $(P<0 \cdot 1)$ between groups.

\section{Discussion}

C. burnetii organisms cause both acute and chronic disease in humans and have been isolated from a wide variety of warm-blooded animals and from arthropods. Previous studies have shown plasmid (Samuel et al., 1985; Vodkin et al., 1986) and LPS (Hackstadt, 1986) differences among isolates, which have allowed the isolates to be grouped. This grouping of isolates appears to correlate with their pathogenic potential, but the degree of variability between groups has not been determined. The present study illustrates that restriction enzyme digestion of chromosomal DNA (Fig. $4 b$ ) can also be used to differentiate these isolates and that the grouping based on plasmid type (Fig. $4 a$ ) is retained. Standard agarose gel separation of RE-generated DNA fragments is useful in that differences are revealed (O'Rourke et al., 1985), but this method is limited because of inadequate band resolution. The use of SDSPAGE analysis and silver staining as described by McClenaghan et al. (1984) allows better fragment pattern resolution, and the number of $C$. burnetii groups is increased to six. Because the technique is highly sensitive, isolates within a group and isolates from different groups are easily distinguishable (Fig. 1).

A reproducible difference between egg-grown phase I and phase II variants of the Nine Mile isolate was previously demonstrated by agarose gel electrophoresis of HaeIII-digested DNA, namely the presence of a DNA fragment of approx. $4.6 \mathrm{~kb}$ in digests of DNA from phase I organisms which was not found in the DNA fingerprint of phase II organisms; however, no other differences were detected when a variety of other restriction enzymes were used to digest DNA from these variants or from phase variants of other strains (O'Rourke et al., 1985). This would seem to suggest that the level of change seen with RE polymorphisms is infrequent during repeated egg or tissue culture passage. This suggestion is further supported by the fact that no differences in DNA fragment fingerprints were observed between passagehistory variants of six $C$. burnetii isolates when analysed by the more sensitive SDS-PAGE procedure used in this study (Fig. 2). Therefore, the variability seen between the groups identified here probably represents significant evolutionary divergence.

The DNA-DNA hybridization data presented here also suggested separation of the isolate groups. While a comparison of the hybridization values for the two experiments did not indicate that the values were statistically significant $(P<0 \cdot 1)$, these values clearly suggest real biological differences. Although DNADNA hybridization has been criticized as a technique for determining the relatedness of different groups, this procedure has previously been used with other rickettsial species to differentiate between species and also between strains within a species (Myers \& Wisseman, 1980). That study found differences in hybridization $(D)$ from 0 to $8 \%$ for rickettsiae of the same species that were previously separated into distinct strains by serological criteria. Thus the three genomic groups tested in our study, viz. groups I, IV and VI, represent three distinct C. burnetii strains. While the results suggest that group V is also a separate strain, the data are not clear on whether groups I, II and III comprise one or three strains. The isolates in these three groups have the same plasmid type, but have different genomic DNA fingerprints and LPS (Hackstadt, 1986) banding patterns. Methods such as filter hybridization (Crosa et al., 1973), restriction 
fragment length polymorphism using randomly generated probes (Nei, 1987) and multilocus enzyme analysis (Selander et al., 1986) could be used to determine the genetic distance between these strains more precisely.

Finally, we propose to use these data to organize individual $C$. burnetii stocks according to a specific nomenclature system. Individual stocks are currently maintained and separately identified that differ with respect to source of original isolation, passage history, and LPS type (phase I or phase II). We propose to use the word 'strain' to indicate the six separate groups as defined previously by plasmid and LPS type, and, in this report, by the banding patterns of RE-digested chromosomal DNA.

This work was supported by Public Health Service grant R01 A120190 from the National Institutes of Health.

\section{References}

BaCA, O. G. \& Paretsky, D. (1983). Q fever and Coxiella burnetii: a model for host-parasite interactions. Microbiological Reviews 47, 127-149.

Crosa, J. H. Brenner, D. J. \& Falkow, S. (1973). Use of a singlestranded specific nuclease for analysis of bacterial and plasmid deoxyribonucleic acid homo- and heteroduplexes. Journal of Bacteriology 115, 904-911.

HaCKSTADT, T. (1986). Antigenic variation in the phase I lipopolysaccharide of Coxiella burnetii isolates. Infection and Immunity $\mathbf{5 2}$ $337-340$.

Hendrix, L. \& Mallavia, L. P. (1984). Active transport of proline by Coxiella burnetii. Journal of General Microbiology 130, 2857-2863.

Herring, A. J., Inglis, N. F., OJeh, C. K., Snodgrass, D. R. \& MENZIES, J. D. (1982). Rapid diagnosis of rotavirus infection by direct detection of viral nucleic acid in silver-stained polyacrylamide gels. Journal of Clinical Microbiology 16, 473-477.
LAEMMLI, U.K. (1970). Cleavage of structural proteins during the assembly of the head of bacteriophage T4. Nature, London 227, 680-685.

DELAY, J. (1970). The quantitative measurement of DNA hybridization from renaturation rates. European Journal of Biochemistry 12 133-142.

Mallavia, L. P., Frazier, M. E., Richardson-Carlson, R. \& SAMUEL, J. E. (1985). Grouping of Coxiella burnetti isolates by restriction endonuclease analysis. In Abstracts of the Annual Meeting of the American Society of Microbiology, D79, p. 67.

Maniatis, T., Fritsch, E. F. \& SAMbrooK, J. (1982). Molecular Cloning: a Laboratory Manual. Cold Spring Harbor, NY: Cold Spring Harbor Laboratory.

McClenaghan, M., Herring, A. J. \& Aitken, I. D. (1984). Comparison of Chlamydia psittaci isolates by DNA restriction endonuclease analysis. Infection and Immunity 45, 384-389.

MYers, W. F. \& Wisseman, C. L., JR (1980). Genomic relationship among the Typhus group of Rickettsiae. International Journal of Systematic Bacteriology 30, 143-150.

NeI, M. (1987). Molecular Evolutionary Genetics. New York: Columbia University Press.

O'Rourke, A. T., Peacock, M., Samuel, J. E., Frazier, M. E., Natvig, D. O., Mallavia, L. P. \& Baca, O. (1985). Genomic analysis of phase I and II Coxiella burnetii with restriction endonucleases. Journal of General Microbiology 131, 1543-1546.

Peacock, M. G., Philip, R. N., Williams, J. C. \& Faulkner, R. S (1983). Serological evaluation of $Q$ fever in humans: enhanced phase I titers of immunoglobulins $G$ and $A$ are diagnostic for $Q$ fever endocarditis. Infection and Immunity 41, 1089-1098.

Samuel, J. E., Frazier, M. E., Kahn, M. L., Thomashow, L. S. \& Mallavia, L. P. (1983). Isolation and characterization of a plasmid from phase I Coxiella burnetii. Infection and Immunity 41, 488-493.

Samuel, J. E., Frazier, M. E. \& Mallavia, L. P. (1985). Correlation of plasmid type and disease caused by Coxiella burnetii. Infection and Immunity 49, 775-779.

Selander, R. K., Caugant, D. A., Ochman, H., Musser, J. M., Gilmour, M. N. \& Whittam, T. S. (1986). Methods of multilocus enzyme electrophoresis for bacterial population genetics and systematics. Applied and Environmental Microbiology 51, 873-884.

Topping, N. H., Shepard, C. C. \& Huebner, R. J. (1946). Q fever. An immunological comparison of strains. American Journal of Hygiene 44, 173-182.

Vodkin, M. H., Williams, J. C. \& Stephenson, E. H. (1986). Genetic heterogeneity among isolates of Coxiella burnetii. Journal of General Microbiology 132, 455-463. 